\title{
Hexasepalum teres (Rubiaceae): A potential New World invasive alien weed from Eastern Ghats
}

\author{
Devanathan, K. ${ }^{1}$ and D. Narasimhan ${ }^{2 *}$ \\ ${ }^{1}$ Centre for Floristic Research, Department of Botany, Madras Christian College (Autonomous), \\ Tambaram, Chennai, Tamil Nadu - 600 059, India \\ ${ }^{2}$ No.5, Santhana Lakshmi Street, Rajeshwari Nagar, Seliyur, Chennai, Tamil Nadu-600 073, India \\ *E-mail: deva.taxo@gmail.com
}

\begin{abstract}
Hexasepalum teres (Walter) J.H.Kirkbr. (Rubiaceae), a Neotropical invasive weed, is reported here for the first time from Eastern Ghats. The occurrence of this species raises alarm of its rapid invasion.
\end{abstract}

Keywords: Eastern Ghats, Hexasepalum teres, invasive weed, Kolli Hills

\section{Introduction}

Introduction of plants is a primordial phenomenon that happened either with a purpose or accidentally. Many of the introduced species have either naturalized or have become invasive. Invasive alien species can be defined as, "A nonnative species to the ecosystem or country under consideration that spreads naturally, interferes with the biology and existence of native species, poses a serious threat to the ecosystem and causes economic loss". A total of 1226 alien species were recorded from Tamil Nadu, of which 200 species have been categorized as naturalized or potentially invasive. About $60 \%$ of these are introduction from the new world region (Narasimhan et al., 2009).

Hexasepalum is a recent segregate genus from Spermacoce-Diodia complex which comprises c. 15 species (Kirkbride \& Delprete, 2015; Cabaña Fader et al., 2016; WCSP, 2018). This is a Neo-American genus except for $H$. vaginale which is restricted to the Atlantic coast of continental Africa (Cabaña Fader et al., 2016). A few species of Hexasepalum have spread to other regions of the world and have naturalized or become invasive. Hexasepalum teres (Walter) J. H. Kirkbr. has been widely reported during the past two decades from tropical regions of Africa, Asia and Australia (Kirkbride, 2014; WCSP, 2018). However in India this alien weed has been reported about three decades ago by Ravi et al. (1989) and remained a very poorly known taxon.
During the floristic exploration in Kolli Hills, a hill range in southern Eastern Ghats of Tamil Nadu, authors collected an unidentified species of the family Rubiaceae. After critical study, the species was identified as Hexasepalum teres, an invasive alien weed. Here we provided an updated nomenclature, detailed description and a photo plate to facilitate identification for researchers and foresters.

Hexasepalum teres (Walter) J.H. Kirkbr., J. Bot. Res. Inst. Texas 8(1): 17. 2014. Diodia teres Walter, Fl. Carol. 87. 1788; Ravi et al., J. Bombay Nat. Hist. Soc. 86 (2): 277. 1989. Diodella teres (Walter) Small, Fl. Lancaster Co. 271. 1913.

Type: UNITED STATES, South Carolina, Georgetown Co., Georgetown, old field, 24.08.1939, R.K. Godfrey \& R.M. Tryon 1682 (Neotype designated by Ward, 2008. GH!; Isoneotypes: NY, US!).

Fig.1

Annual herbs, stems erect or decumbent, branched, up to $45 \mathrm{~cm}$ high, scabrous with hirsute, woody. Leaves sessile or subsessile, blade linear, apex acute, base subcordate, margins scabrid-ciliate, apices with a prominent setae, $13-25 \times 3-7 \mathrm{~mm}$, scabrous; stipules, connate with petiole, bristly at apex; fimbriae 9-11, 4-6 mm long. Inflorescence axillary, 1-4 flowered. Flowers c. $5.5 \times 3 \mathrm{~mm}$, sessile. Calyx 4-lobed, glabrous to scabrous outside, persistent; lobes unequal, ovate - lanceolate, $0.6-1.5 \times 0.3-0.6$ $\mathrm{mm}$, scabrous at margins, acute, setose at apex. Corolla infundibuliform, c. $4.2 \mathrm{~mm}$ long, scabrous, 

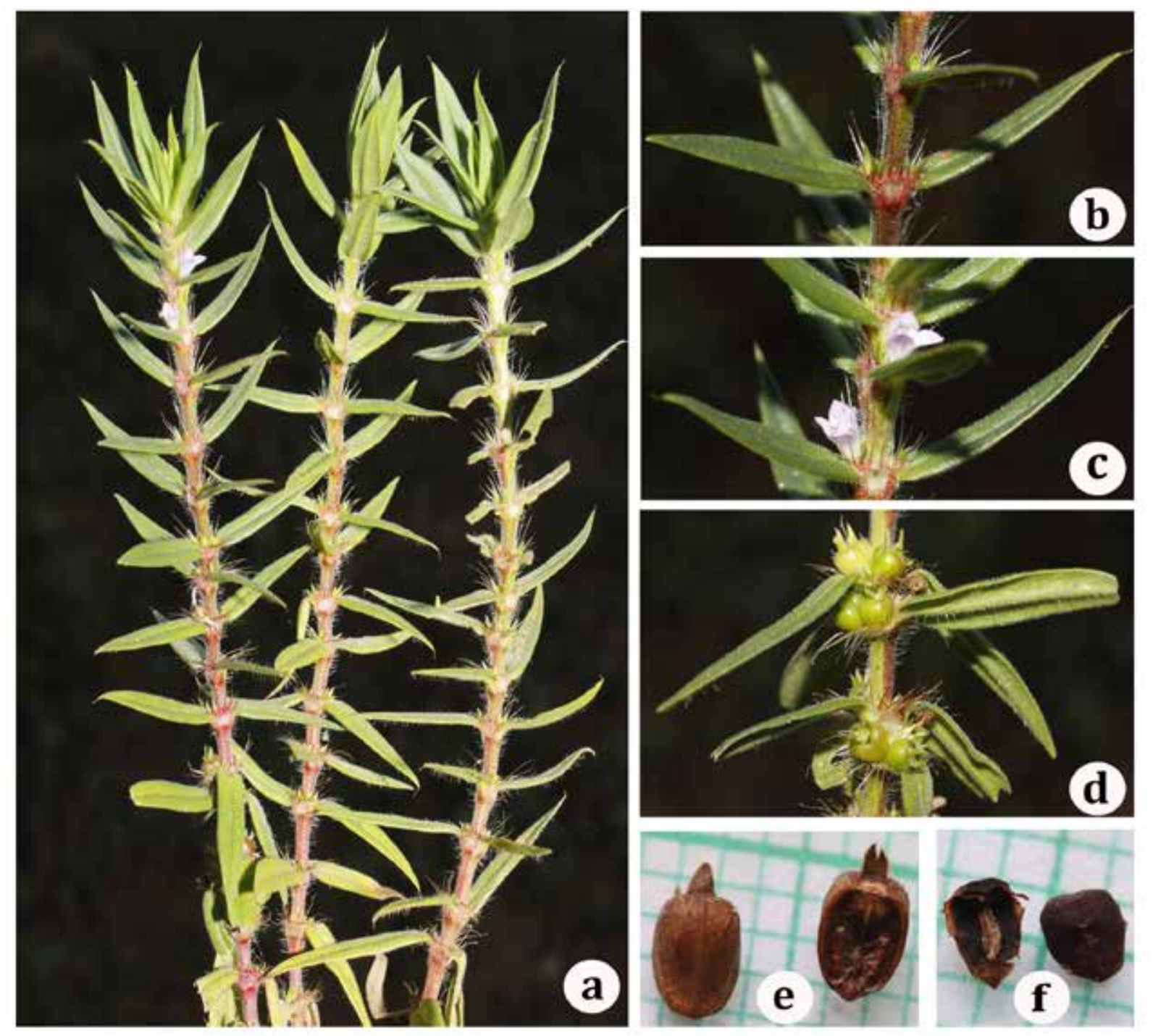

Fig. 1. Hexasepalum teres (Walter) J.H. Kirkbr.: a. Habit; b. Close-up view of stipule; c. Close-up view of flowers; d. Close-up view of fruits; e. Dorsal and ventral view of mericarps; $\mathbf{f}$. Ventral and dorsal view of seeds

pale purple; tube 3-3.4 $\mathrm{mm}$ long, glabrous with a ring of hairs at base inside; limb 4-lobed; lobes ovate, $c .1 .8 \times 1.2 \mathrm{~mm}$, ciliolate at margins, acute at apex, scabrous. Stamens 4 , exserted. Hypanthium obconical, c. $1 \times 1 \mathrm{~mm}$, scabrid. Ovary obovoid, $c$. $1 \times 0.8 \mathrm{~mm}$, truncate at apex, scabrid; style 3-3.5 $\mathrm{mm}$ long; stigma 2-lobed, each lobe globose, papillate. Capsules obovoid to obconical, 2.2-3 $\times 1.7-2 \mathrm{~mm}$, sparsely hispid above, crowned by persistent calyx; mericarps 2, indehiscent, dorsally 1-3 carinate; seeds obovoid to obconical, c. 2.2-2.8 $\times 1.8 \mathrm{~mm}$, incurved at apex, dorsally concave with shallow groove, ventrally sulcate with $\mathrm{Y}$ shaped depression, coarsely reticulate, dark brown.

Flowering \& fruiting: July - December.

Habitat: H. teres is found growing from coast to hill top, moist open rocks in evergreen forest margins, stream banks and margins of the cultivated lands above $1200 \mathrm{~m}$.

Associated species: This species grows along with Chamaecrista mimosoides (L.) Green, Cyanotis arachnoidea C.B. Clarke, Cyanotis pilosa Schult. \& Schult.f., Fimbristylis dichotoma (L.) Vahl., Habenaria longicornu Lindl., Heliotropium scabrum Retz., Justicia simplex D. Don, Mitracarpus hirtus (L.) DC., Murdannia spirata (L.) G. Brückn., Oldenlandia herbacea (L.) Roxb. and Spermacoce latifolia Aubl.

Distribution: A native of tropical American regions (U.S.A., Mexico, Cuba, Hispaniola, Jamaica, Margarita, Belize, Guatemala, Honduras, El. Salvador, Nicaragua, Costa Rica, Panama, Colombia, Venezuela, Guyana, Surinam, French Guiana, Ecuador, Peru, Bolivia, Brazil, Paraguay), introduced in Australia, Cape Verde, Gambia, 
Guinea-Bissau, India, Japan, Korea, Madagascar, Netherland, Senegal, Southeast China and Sri Lanka.

Specimens examined: INDIA, Kerala, Kollam district, S.N. College campus, Chathannoor, 10 m, 6.7.1988, Ravi 2429 (CAL). Tamil Nadu, Namakkal district, Kolli Hills, Vazhavandhi RF

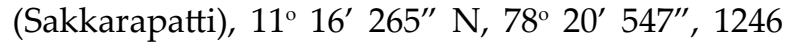
m, 27.8.2015, Devanathan 10023; Vazhavandhi RF (Slope near Botanical garden view point), 11 $16^{\prime}$ 390" N, 78 19' 054", 1199 m, 30.9.2016, Devanathan 10915; Periyasami koil solai (Maasilaaruvi) $11^{\circ} 18^{\prime}$ 359" N, 78 23' 511", 1144 m, 1.10.2016, Devanathan 10949; Vazhavandhi RF (Semmedu) 11' 17' 184" N, 78 19' 968", 1126 m, 22.2.2018, Devanathan \& Narasimhan 11218 (CAL).

Notes: The species has been reported as an invasive weed in cultivated fields including in its native range (Jordan, 1989, 1991). The first report of this species in India is by Ravi et al. (1989) as a weed from an institutional campus and adjacent areas of Chathannoor, a Coastal town in present day Kollam district of Kerala state. It could be an accidental introduction in to India by the searoute along with horticultural plant trade. It is noted in three different locations of forest regions as well as margins of cultivated lands of Kolli Hills with sizable population. This indicates $H$. teres is naturalizing rapidly and if unchecked can become invasive. Since Kolli Hills known for its horticultural crops such as Pepper, Tapioca and Coffee, this species has probably made its entry in to the Eastern Ghats through horticultural activities. Its occurrence elsewhere in the Eastern Ghats and Western Ghats need to be explored. $H$. teres has been reported as a difficult weed to eradicate probably due to the thick wall of the mericarp that protects the seed from weedicides and render resistance for mechanical removal (Cabaña Fader et al., 2016). Hence it is important to take urgent measures to control further spread of the species.

\section{Acknowledgements}

We thank Dr. R.K. Upadhyay IFS, PCCF (Research) and Forest officials, Namakkal Forest division, Tamil Nadu Forest Department for granting permission to carry out research in Kolli Hills; Dr. I. Oliver King, Principal Scientist, M.S. Swaminathan Research Foundation, Namakkal for help during the field visits and Drs. E.L. Cabral and R.M. Salas, Instituto de Botánica del Nordeste, Argentina for their opinion on the identification.

\section{Literature Cited}

Cabaña Fader, A.A., Salas, R.M., Dessein, S. \& E.L. Cabral 2016. Synopsis of Hexasepalum (Rubiaceae), the priority name for Diodella and a new species from Brazil. Systematic Botany 41(2): 408-422.

Jordan, N. 1989. Path analysis of growth differences between weed and non-weed populations of Poorjoe (Diodia teres) in competition with Soybean (Glycine max). Weed Science 37: 129136.

Jordan, N. 1991. Multivariate analysis of selection in experimental populations derived from hybridization of two ecotypes of the annual plant Diodia teres W. (Rubiaceae). Evolution 45(8): 1760-1772.

Kirkbride, J.H. 2014. Hexasepalum teres (Rubiaceae), a new combination. J. Bot. Res. Inst. Texas 8(1): 17-18.

Kirkbride, J.H. \& P.G. Delprete 2015. New combinations in Hexasepalum (Rubiaceae: Spermacoceae). J. Bot. Res. Inst. Texas 9: 103106.

Narasimhan, D., Arisdason, W., Sheeba, J.I. \& G. Ganasekaran 2009. Invasive alien plant species of Tamil Nadu. Proc. Sem. Invasive Alien Species pp. 29-38.

Ravi, N., Anilkumar, N. \& T.K. Balachandran 1989. Diodia L. (Rubiaceae): A new generic report from India. J. Bombay Nat. Hist. Soci. 86(2): 276-278.

Smithsonian National Museum of Natural History. Available at: http://collections.nmnh. si.edu/search/botany [Accessed on 24.03.2018].

WCSP. 2018. World Checklist of Selected Plants Families (Rubiaceae). The Royal Botanic Gardens, Kew. Available at: http://wcsp. science.kew.org. [Accessed on 13.02.2018].

Received: 26.03.2018

Revised and Accepted: 22.05.2018 